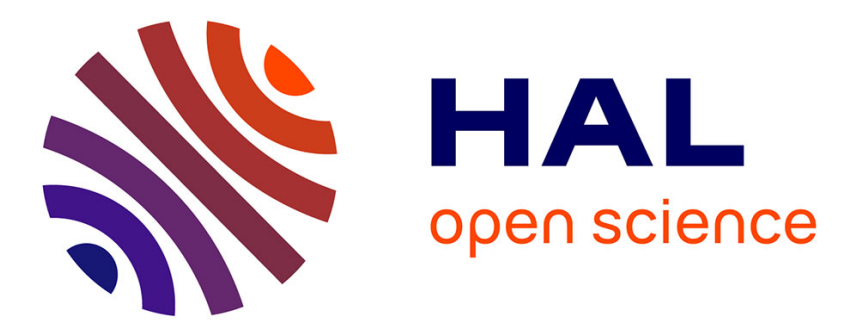

\title{
Mapping intermediaries in contemporary art according to pragmatic sociology
}

\author{
Nathalie Heinich
}

\section{To cite this version:}

Nathalie Heinich. Mapping intermediaries in contemporary art according to pragmatic sociology.

European Journal of Cultural Studies, 2012, 15 (6), pp.695-702. halshs-01202777

\section{HAL Id: halshs-01202777 \\ https://shs.hal.science/halshs-01202777}

Submitted on 10 Nov 2015

HAL is a multi-disciplinary open access archive for the deposit and dissemination of scientific research documents, whether they are published or not. The documents may come from teaching and research institutions in France or abroad, or from public or private research centers.
L'archive ouverte pluridisciplinaire HAL, est destinée au dépôt et à la diffusion de documents scientifiques de niveau recherche, publiés ou non, émanant des établissements d'enseignement et de recherche français ou étrangers, des laboratoires publics ou privés. 
Nathalie HEINICH

heinich@ehess.fr

CRAL (EHESS)

96, Bd. Raspail

75006 Paris

Tel. 0033142099318

Nathalie HEINICH, born in 1955, is research director in sociology at the Centre National de la Recherche Scientifique (CNRS, Paris). She specialized in the sociology of arts (artistic professions, aesthetic perception, conflicts about contemporary art), socio-anthropology of identity crisis (in fiction, authorship or survivors testimonies), women's identity ("states" of women and mothers-daughters relationship), and the epistemology of social sciences.

Potential referees:

- David Inglis (d.ingliseabdn.ac.uk)

- Sophia Kris Acord (Sophiaemusicandartsinaction.net) 


\section{MAPPING INTERMEDIARIES IN CONTEMPORARY ART ACCORDING TO PRAGMATIC SOCIOLOGY}

A new trend appeared during the 1990's in French sociology, named "pragmatic sociology". It refers both to the American "pragmatism" in philosophy and to "pragmatic" linguistics (Heinich, 2009a). Besides a number of differences according to its various authors (Boltanski and Thévenot, 2006; Hennion, 2007; Latour, 2002), it mainly stands on empirical surveys grounded in close observation of actions in their actual context. It thus represents not only "a growing strand of cultural theory" (Silber, 2003: 427) but also an important renewal. As it pretends to be mostly descriptive and analytical rather than critical, it breaks with Pierre Bourdieu's "sociology of domination" (Heinich, 1998b; Heinich, 2009b); and as it considers that the relativity of human actions according to their contexts is now but a commonsensical issue, which does not need anymore to be demonstrated but only used as a starting point for analysis, it tends to overpass the anglo-american "cultural studies" and "social constructivism" (Heinich 2010; Heinich 2011).

In the field of the sociology of arts, this "pragmatic" perspective cannot be reduced to Howard Becker's demonstration of the collective nature of artistic activities (Becker, 1982), since it does not pretend to demonstrate anything, nor to dismiss the commonsensical belief in the individual nature of artistic experience: rather, the pragmatic sociological approach to arts aims at describing the close intertwining of situated human actions and objects, in order to understand the whole set of frames (including symbolic frames such as representations and values) which constraint and organize actual relationships to art.

Let us give here but one example of how the pragmatic perspective can help describing and understanding what is at stake in such or such situation related to arts. When commenting on Marcel Duchamp's readymades, scholars often pretend that he would have declared "This is art"; but such a statement is absolutely untrue, as demonstrated by a close account of what actually happened. Duchamp did not say anything: he did something (buy a urinal, paint a signature and a date on it, bring it to the hall where the Salon des Indépendants in New York received the art works, place it in a reverse position), then, after the urinal was let alone in a lobby (but not "refused", since there was no jury), he let other people act. First, he let his friend Alfred Stieglitz publish a photography of Fountain and a comment on it in his journal The Blind Man; and then... he just waited. Nearly forty years later, once he had become a leading figure in modern art, he decided to make a small number of replicas of the 
original urinal (which had been lost) and sell them to private galleries and public museums. This means that he just let cultural intermediaries do their work: treating and framing the thing as a work of art, insuring it, describing it, selling or exhibiting it, lighting it, commenting it (Camfield 1989, Heinich 1998). Thus Duchamp did with his actions what a "pragmatic" sociologist would have done with words: that is, provide evidence of how important intermediaries are in the field of art.

Focusing on cultural intermediaries is not, indeed, quite a novelty in sociology. But this issue has mostly been addressed either regarding "minor" cultural productions, such as culture industries, advertising, fashion or graphic design (Nixon and Du Gay, 2002; Cronin, 2004); or regarding side aspects of artistic activities, such as the art market (Joy and Sherry, 2004). Considering the role of cultural intermediaries in "major" artistic activities such as the visual arts remains a somehow marginal issue in sociology (Michaud, 1989; Greenberg, Ferguson and Nairne, 1996; Heinich, 2007). This paper intends to frame the various ways to address it in the specific domain of contemporary visual arts.

\section{One contemporary example}

The scene takes place in September 2008, during the press opening of a major exhibition at the last floor of the Centre Pompidou's Musée national d'art moderne in Paris. In the second room, in front of a huge canvas, a tiny old man in an elegant grey suit is facing a dozen photographers, with some kind of embarrassment in his shy smile.

Obviously, he is the artist, to whom this big retrospective - the first one in his whole career - is dedicated in this prestigious place. His name is Jacques de la Villeglé. Some sixty years ago, he began to carefully pull out publicity posters stuck on the city walls, bring them into his studio, then stick them on a support, sign them, and eventually exhibit and sell them as his own works.

An art historian would tell us how these "torn" posters ("affiches lacérées", as the artist says) entered art history, took place in a new trend together with the works of a few other artists, and may be influenced by previous ones or influence forthcoming other ones. An art economist would describe how these works progressively entered the "first market" of galleries, then the "second market" of auctions, or even of museums, and how their price went up and up. An historian of culture, or an old style art sociologist, would explain how this work may be read as a visual testimony of the urban French landscape in post-war decades, with its specific publicity practices and graphic fashions. A social philosopher would comment on consumption society and the deconstruction of the "société du spectacle" through its images. 
A critical sociologist would denounce how long it took for "society" to recognise an innovative artist, or how unfair it is to "legitimize" a "pseudo" art work made for "dominants" who "manipulate" culture in order to serve their "distinction strategies" (Bourdieu and Haacke, 1994).

As for a professional art sociologist, he would have to choose between an analysis of the artist's production (the space of competition in which the artist took place, his social origins, the collective movements in which he was involved, his position in the contemporary art world...), an analysis of his reception (statistics measuring his presence in specialized or general press, analysis of the arguments used by critics to qualify and evaluate his work, surveys on the exhibition's visitors...), and an analysis of the various mediations that occurred between the first poster brought back to his studio and this final retrospective in a prestigious museum...

...And there, he will meet a number of heterogeneous beings: humans and objects, words and numbers, walls and institutions: that is, a whole set of "mediations", according to Antoine Hennion's definition of this term (Hennion 1993); in other words, the series of operations which unable an art work to be perceived and appropriated by others than its creator. In this very case, it means the various operations according to which the work has been turned from the underground of nightly removal in the streets of Paris onto the blinding flashes of the cameras in the museum room, where what once used to be garbage posters are going to be exhibited to crowds of visitors under carefully calculated lightings.

What then happened here? First, time: more than two generations. Artists's long lasting is a primary condition for them to be recognised while still living, at least in modern times, when innovation as a requisite in art prevents short time recognition by lay people, as the Van Gogh case clearly demonstrates (Heinich 1996).

Then, there were people: other artists, who happened to form a group at the beginning of the 1960's; an art critic, Pierre Restany, who baptised it ; gallery owners, who decided to show some of these works; art collectors, who bought them; other art critics, who wrote about them; auctioneers, who sold them in public auctions; experts, who authenticated or priced them; museum curators, who persuaded their peers to buy them (firstly in 1971, that is, about 25 years after the first poster removal); art historians, who began to study the artist's whole work; students, who dedicated their $\mathrm{PhD}$ to it; and also framers, transporters, insurers, restorers, printers, electricians, exhibition architects, attendants, lecturers and, eventually, photographers... Without all these people, there would have been no "art works" but only old posters stored in a studio. 
Also, a number of objects were involved: frames, picture rails, spots, gloves, thermometers, hydrometers, labels, art magazines, books, photographs, catalogues, archives, contracts - without forgetting the most important: walls of galleries and museums... Words had their part too: signature of the artist on each work, name of a new group ("Nouveaux réalistes"), name of a new genre («lacéré-anonyme »), names of galleries and museums, comments on the work, biographical data collected by specialists, writing of juridical contracts between a gallery and the artist, between a museum and the private collectors who own a work... (the spanish art historian Juan-Antonio Ramirez accurately speaks of "human operators", "narrative operators" and "icono-verbal operators": Ramirez 1994). Let us not forget numbers: dates on the works and on the labels, lists of prices in galleries, costs of insurances...

All these mediations are exactly the same as those required by any museum exhibition of a painting. What differs here is simply that passing from the studio to the museum is more difficult in the case of a contemporary art work, since its very nature is to challenge art boundaries such as they are traditionally conceived: in the case of classic and modern art, it means framed paintings or sculptures standing on a socle, created by the artist's hand, longlasting, easily transportable, and supposed to convey either an aesthetical aim or, at least, an expression of the creator's interiority (Heinich 1998; Heinich 1999).

Hence another kind of mediations has to be added to the list: that is, mental representations proper to the various categories of actors. But contrary to people, objects, words and numbers, these representations cannot be directly observed: they may be perceived only through the comments on the works expressed in actual situations (or sometimes even through gestures, as in the case of vandalism: Gamboni 1997). These cognitive frames, or mental boundaries, or "symbolic boundaries" (Lamont 1992) appear as generic classifications (DiMaggio 1987), axiological criteria, biographical models (Wittkower 1963); they are more or less incorporated in visual or corporal abilities. They all constitute art mediations, commanding both the introduction of a work into a category and its positioning on a value scale.

The implicit artistic criteria more or less shared by people in a certain context are thus fundamental mediations, although they are little perceivable unless specific investigation. As soon as some of the criteria necessary to consider an art work as such are missing (which is the case for most of them in the "affichistes's" works), the mediations necessary to its artistic accreditation are heavier, and thus longer to obtain. Hence the emotion of who, by chance, observes this brief moment when the artist is being, at least, "recognised" - in all the 
meanings of the term, since the image of his face, and not only of his works, will soon be reproduced in public space owing to the work of the photographers holding up their cameras in front of him, shooting and shooting...

\section{A historical perspective on cultural intermediaries}

As long as visual arts were a craftsmanship (at the time of guilds), or a profession (at the time of academies), their commodification mainly lied on personal transactions, be them in a shop or through commissions (Heinich 1993). But since they pertained to the "vocational" regime of "art", as this term use to be understoodd in modern times (roughly from the second half of the $\mathrm{XIX}^{\circ}$ century), art market became what it means for us nowadays: specialized intermediaries dealing with the circulation of art works (art merchants) and with their evaluation (art critics). American sociologists Harrison and Cynthia White have accurately evidenced the development of the French art market in the second half of the XIXth century, or rather (since an art market had always existed, but in less specialized forms) of the modern art market (White 1965): what they called the "merchants-critics system", as opposed to the classical academic and neo-academic system (Heinich 2005).

Those were the premises of what became a heavy trend in contemporary art since the second half of the $\mathrm{XX}^{\circ}$ century: the growing importance of art intermediaries, together with the "autonomisation" of art (Bourdieu 1992). The reason is simple: the closer art comes to artists' and specialists' favourite issues (on top of them, originality and the place of the work in art history), the farther it goes from mere amateurs and, all the more, from the general public: hence the necessity of specific mediations between the production of the work and its reception. The thickness of mediation, which means the number and importance of cultural intermediaries, grows together with the "autonomy of the field", in Bourdieu's terms.

The image of a "chain" of mediations or intermediaries is sometimes used to describe this process. But such an image might be deceptive. A more relevant image should be the one used by art historian Alan Bowness when trying to explain "how the modern artist rises to fame" (Bowness 1989). He evidences the existence of four "circles of recognition": first, peers; then, critics and curators (often bound to public institutions); third, merchants and collectors (pertaining to the private market); fourth, the general public. One after the other, each of these circles is more and more populated (from a few peers to crowds of museum audiences), later and later (from short time recognition by peers to posthumous fame), and less and less competent. 
Thus this model allows crossing three dimensions: first, the spatial proximity to the artist (he may personally know his/her peers, maybe some of his/her specialists, merchants or collectors, but not his/her audience); second, the temporality of recognition (rapidity of peers' judgement, short or middle term for specialists and amateurs, long term for lay people); and third, the relevance of this recognition according to the judges' competence.

This model also evidences an important difference between modern and contemporary art : in contemporary art, what used to be the second circle in modern art (merchants and collectors) tends to become the third one, since the institutional circle of curators and art critics gets closer to the artists and more immediately involved in his/her recognition (Heinich 2005).

Any mediation is ambivalent: exactly as a screen, it is considered either as what provides or as what blurs visibility, so that it may always be perceived either positively, as what brings the spectator closer to the art work, or negatively, as what separates him/her from the work. This is why people often dismiss the excessive role played by curators, who use to be criticized in that they would pretend to be genuine "authors" of the exhibitions they organize, thus in a way competing with the artists they exhibit (Michaud 1989; Heinich and Pollak 1996; Heinich 1995).

\section{Cultural intermediaries in the French contemporary context}

The case of France is particularly interesting regarding the issue of cultural intermediaries. In this country their role became increasingly important for contemporary art. A new professional group arose in the 1970s and developed in the 1980s, after the Left came to power in 1981, fostering an active policy conceived both as a help to creators and as a democratization of culture. Within the visual arts, the number of state-salaried civil servants has multiplied, at the same time as they have been given much wider duties than those carried out by the traditional corps of museum officials: exhibition curators and/or art critics, directors of the regional funds for contemporary art (Fonds Régionaux d'Art Contemporain, FRAC), art advisers in regional cultural directorates (Directions Régionales des Affaires Culturelles, DRAC) or for the Ministry of Culture (inspecteurs à la creation), project managers in the regional authorities... They are active in an ever growing sector, with increasingly specialised academic educational pathways.

These circumstances are relatively unknown, although they have major consequences, some of them deemed damaging and other deemed good: modernisation of the museums, growing number of public art exhibitions, establishment of specific departments in the major 
museums in order to promote a democratisation of the audience, creation of artotheques (institutions for lending out works of art, mostly graphic art ), artists' housing, and a number of other supporting measures (help in putting on first exhibitions, allocation of studios, grants for journeys abroad, etc).

This reality is often undervalued or even ignored. Little is known about this professional group, its morphological profile (size, age distribution and social origins, degrees, salary conditions etc), the way people are selected, peer appraisal, determination of competence etc. Forthcoming surveys should particularly focus on the strong mutual interdependence which marks this new professional group, as many of its members know each other personally. All of this leads to a fairly high degree of conformity, unswerving loyalty when the group is questioned by outsiders, and a worldwide method of corporatist defence in the name of art and culture. But it also leads to a considerable rivalry, particularly in the competition to discover new, unknown talent, that is artists who are either very young, or foreigners. This partly explains why confirmed French artists so seldom attract attention inside France, and why so many young artists appear, even before having completed their training and having proved their worth on the market or showed a personal development potential other than simply desmonstrating their understanding of the rules of the game.

\section{Mapping cultural intermediaries in contemporary art}

Far beyond the French context, contemporary art possesses special properties which directly influence its relationship to intermediaries. The difference between modern and contemporary art is not firstly chronological, but generic: the "genre" of contemporary art fundamentally differs from the "genre" of modern art, since the former mainly relies on the transgression of the boundaries of art such as they are commonly conceived, whereas the latter is supposed to express the interiority of the artist, be it by transgressing the rules of academic figuration - rules that classic art is expected to enact (Heinich 1998; Heinich 1999).

This peculiar relationship to common sense expectancies opens a gap between contemporary art works and the capacity of the general public to accept or understand them. This is the major reason why cultural intermediaries are a fundamental component of the field of contemporary art: without specialized curators, critics, lecturers, merchants, auctioneers, not any installation, performance or contemporary painting could successfully move from the artist's studio (or the artist's mind) to a public place, let alone to any private home. Contemporary art thus provides a privileged ground for the sociological study of mediations, and especially of cultural intermediaries - as evidenced in the case of Jacques de la Villeglé. 
We spontaneously figure out the aesthetic relation as binary, between a work and a receiver. In fact it is actually a triadic relation between works, the public and a number of mediation processes - publication, dissemination, organisation, production, commentaries, material and mental frameworks... These processes are operated by individuals who act as intermediaries in the art world; much more than art works and artists, and as well as spectators, they are a perfect scope for sociological investigation. As art historian JuanAntonio Ramirez accurately wrote, "one has to stop believing that genuine creation directly passes from the artist's studio to the spectator's eye" (Ramirez 1995: 20). This new perspective opens the way for a number of surveys using the methods of pragmatic sociology and ethnology in order to describe and understand the very actions of all these cultural intermediaries. 


\section{REFERENCES}

Becker, H. (1982), Art Worlds, Berkeley, University of California Press.

Boltanski, L. and Thévenot, L. (2006) On Justification. The Economies of Worth, Princeton, Princeton University Press.

Bourdieu, P. (1992) Les Règles de l'art. Genèse et structure du champ littéraire, Paris, Seuil.

Bourdieu, P. and Haacke H. (1994) Libre échange, Paris, Seuil-Les presses du réel.

Bowness, A. (1989) The Conditions of Success. How the Modern Artist Rises to Fame, London, Thames and Hudson.

Camfield, William A. (1989) Marcel Duchamp, Fountain, The Menil Collection, Houston Fine Art Press.

Cronin, A. (2004), "Regimes of Mediation: Advertising Practitioners as Cultural

Intermediaries", Consumption, Markets and Culture, vol. 7, n 4, pp. 349-369.

DiMaggio, P. (1987) “Classification in Art”, American Sociological Review, vol. 52, august.

Gamboni, D. (1997) The Destruction of Art. Iconoclasm and vandalism since the French Revolution, London, Reaktion books.

Greenberg R., Ferguson B., Nairne S. (eds.), (1996) Thinking about exhibitions, London, Routledge.

Heinich, N. (1993) Du peintre à l'artiste. Artisans et académiciens à l'âge classique, Paris, Minuit.

Heinich, N. (1995) Harald Szeemann, un cas singulier. Entretien, Paris, L'Échoppe.

Heinich, N. (1996) The Glory of Van Gogh, 1991, Princeton University Press.

Heinich, N., Pollak, M. (1996) "From Museum Curator to Exhibition Auteur: Inventing a singular position", in Greenberg R., Ferguson B., Nairne S. (eds.), Thinking about exhibitions, London, Routledge (first published 1989).

Heinich, N. (1998a) Le Triple jeu de l'art contemporain, Paris, Minuit.

Heinich N. (1998b) Ce que l'art fait à la sociologie, Paris, Minuit.

Heinich N. (1999), « Pour en finir avec la querelle de l'art contemporain », Le Débat, n 104.

Heinich, N. (2005) L'Élite artiste. Excellence et singularité en régime démocratique, Paris, Gallimard.

Heinich, N. (2007) Faire voir. L'art à l'épreuve de ses médiations, Paris, Les Impressions nouvelles. 
Heinich, N. (2009a) La Fabrique du patrimoine. De la cathédrale à la petite cuillère, Paris, éditions de la Maison des sciences de l'homme.

Heinich N. (2009b) "The Sociology of Vocational Prizes: Recognition as Esteem”, Theory, Culture and Society, 26, 5.

Heinich, N. (2010) "What does « Sociology of Culture » mean ? Notes on a Few Trans-Cultural Misunderstandings", Cultural Sociology, 4 (2).

Heinich, N. (2011, forthcoming) “The Making of Cultural Heritage", European Journal of Aesthetics.

Hennion, A. (1993) La Passion musicale. Une sociologie de la médiation, Paris, Métailié.

Hennion, A. (2007), "Ce que ne disent pas les chiffres. Vers une pragmatique du goût", in Assouly O. (ed.), Goûts à vendre. Essai sur la captation esthétique, Paris, IFM/Regard, pp. 95-116.

Joy, A. and Sherry Jr, J. (2004), "Framing Considerations in the prc: Creating Value in the Contemporary Art Chinese art market", Consumption, Markets and Culture, vol. 7, n 4, pp. 349-369.

Lamont, M. (1992) Money, Morals and Manners. The Culture of the French and American Upper Middle Class, Chicago University Press.

Latour B. (2002), La Fabrique du droit. Une ethnographie du Conseil d'Etat, Paris, La Découverte.

Michaud, Y. (1989), L'Artiste et les commissaires, Nîmes, Jacqueline Chambon.

Nixon, S. and Du Gay, P. (2002), “Who needs Cultural Intermediaries?”, Cultural Studies, vol. $16, \mathrm{n}^{\circ} 4$, pp. 495-500.

Ramirez J.-A. (1995) Les Usines à valeurs. Ecosystème des arts et explosion de l'histoire de l'art, Nîmes, Jacqueline Chambon (first published in 1994).

Silber I. (2003) "Pragmatic Sociology as Cultural Sociology : Beyond Repertoire Theory ?", European Journal of Social Theory, ${ }^{\circ}$ 6, pp. 427-449.

White, H. and C. (1965) Canvases versus Careers. Institutional Change in the French Painting World, University of Chicago Press.

Wittkower R. and M. (1963), Born under Saturn. The Character and Conduct of Artists, New York, Norton. 


\section{SUMMARY}

The role and number of intermediaries involved in the process of artistic mediation tend to be all the more important as the art world becomes more autonomous, ruled by specific values, words and actions. This is particularly obvious in the case of contemporary visual arts, as this paper demonstrates. The example of a French member of the "Nouveaux Réalistes" movement helps mapping the various categories of persons, institutions, gestures, objects owing to which a piece of scrap may be offered the career of an authentic art work. The paper eventually provides a historical explanation of the growing role of intermediaries in modern and contemporary art, and an insight on the French present time cultural policy concerning intermediaries in the visual arts.

\section{KEY WORDS}

Art - Contemporary art - Cultural policy - Intermediaries - Mediations - Pragmatism Sociology - Visual arts - 